\title{
POTENSI EKSTRAK DAUN CAMELLIA SINENSIS SEBAGAI UPAYA PREVENTIF TERHADAP SERANGAN ASMA
}

\author{
Angelica Riadi Alim Suprapto,'
}

'Program Studi Pendidikan Dokter, Fakultas Kedokteran, Universitas Indonesia, Jakarta

\begin{abstract}
ABSTRAK
Korespondensi:

Angelica Riadi Alim

Email author:

licaalim@gmail.com

Riwayat Artikel

Diterima: 15 Maret 2021

Selesai revisi: 1 Juli 2021

DOI :

10.53366/jimki.v9i1.328

Pendahuluan: Asma adalah penyakit respiratorik yang memiliki prevalensi tinggi di seluruh dunia. Salah satu gejala asma adalah serangan asma, yaitu sesak napas. Gejala ini dapat berakhir fatal jika tidak diatasi dengan baik. Kematian akibat asma tidak sering, tetapi menjadi perhatian karena sebagian besar dapat dicegah. Camellia sinensis (C. sinensis) dapat berfungsi sebagai bronkodilator sehingga penggunaan ekstrak daun $C$. sinensis dapat menjadi solusi yang tepat dalam upaya preventif terhadap serangan asma dan menurunkan angka mortalitas asma.

Metode: Tinjauan Pustaka ini disusun dengan cara meninjau beberapa sumber ilmiah dengan beberapa kata kunci. Selanjutnya penulis menganalisis, meninjau dan memilah referensi yang relevan. Terdapat sekitar 14 sumber ilmiah yang dianalisis dan ditinjau terkait $C$. cinensis dan asma dalam artikel ini.

Pembahasan: Kandungan kafein dalam daun Camellia sinensis $(C$. sinensis) dapat berfungsi sebagai bronkodilator sehingga penggunaan ekstrak daun C. sinensis dapat menjadi solusi yang tepat dalam upaya preventif terhadap serangan asma dan menurunkan angka mortalitas asma.

Simpulan: Penggunaan ekstrak daun Camellia sinensis berpotensi sebagai upaya preventif terhadap serangan asma.
\end{abstract}

Kata Kunci: Asma, Camellia Sinensis, Kafein

\section{CAMELLIA SINENSIS LEAF EXTRACT AS A POTENT PREVENTIVE MEASURE OF ASTHMA ATTACK}

\begin{abstract}
Background: Asthma is a respiratory disease that has a high prevalence worldwide. One of the symptoms of asthma is an asthma attack, which is shortness of breath. This symptom can be fatal if not treated properly. Asthma deaths are not frequent, but a cause for concern because they are largely preventable. Camellia sinensis (C. sinensis) can function as a bronchodilator such that the use of $C$. sinensis leaf extract can be the right solution in preventing asthma attacks and reducing asthma mortality rates.

Methods: This article is structured by reviewing several scientific sources with several key words. Furthermore, the authors analyze, review and sort out relevant references. There are about 14 scientific sources analyzed and reviewed regarding C. sinensis and asthma in this article.

Discussion: The caffeine content in Camellia sinensis leaves can function as a bronchodilator so that the use of $C$. sinensis leaf extract can be the right solution in preventing asthma attacks and reducing asthma mortality.

Conclusion: The use of Camellia sinensis leaf extract has the potential as a preventive measure against asthma attacks.
\end{abstract}




\section{Keywords: Asthma, Camellia Sinensis, Caffeine}

\section{PENDAHULUAN}

Asma adalah penyakit respiratorik yang memiliki prevalensi tinggi di seluruh dunia $^{[1]}$. Salah satu gejala asma adalah serangan asma, yaitu sesak napas. Gejala ini dapat berakhir fatal jika tidak diatasi dengan baik. Diantara 235 juta penderita asma di seluruh dunia, 489,000 orang diantaranya meninggal dunia ${ }^{[2]}$. Berdasarkan Global Asthma Report 2018, kematian di dunia akibat asma hanya sebesar kurang dari $1 \%$. Bahkan di beberapa negara, seperti Amerika Serikat, tersebut telah mengalami penurunan dari tahun ke tahun. Sedangkan pada tahun yang sama, prevalensi penyakit asma di Indonesia adalah sebesar 2,4\%. Jika dibandingkan dengan data pada tahun 2007, terdapat kenaikan prevalensi penyakit asma sebesar 0,5\%. Angka mortalitas tersebut tidak besar, tetapi perlu diperhatikan karena sebagian besar kematian akibat asma dapat dicegah ${ }^{[3,4]}$.

Dengan prevalensi asma yang semakin meningkat, jelas bahwa Indonesia masih jauh dari target yang telah ditetapkan dalam Sustainable Development Goals (SDGs) 2030. Target ke-4 dari tujuan ke-3 SDG 2030 adalah "pada tahun 2030, mengurangi sepertiga dari kematian dini yang disebabkan oleh penyakit tidak menular, melalui tindakan pencegahan dan pengobatan serta menaikkan kesehatan mental dan kesejahteraan"[5]. Asma merupakan salah satu penyakit yang tidak menular ${ }^{[1]}$. Demi mencapai target tersebut, pengobatan yang diperikan kepada penderita asma harus dapat mencegah atau mengatasi serangan asma yang menyebabkan beberapa penderita asma meninggal dunia ${ }^{[2]}$. Harapannya, dengan mencegah gejalagejala yang dapat berakibat fatal, angka mortalitas akibat asma dapat berkurang dan target ke-4 dari tujuan ke-3 SDGs 2030 dapat tercapai.

Sehubungan dengan SDGs 2030, upaya untuk mengurangi tingkat kejadian asma di Indonesia bukan tanpa dasar. Asma dapat menurunkan kualitas hidup orang yang menderitanya. Obstruksi saluran napas yang dialami oleh penderita dapat menghilangkan kenyamanan. Sebuah penelitian yang dilakukan oleh Harrio MS dan Kartini K membuktikan bahwa kualitas hidup $86,5 \%$ responden yang menderita asma terganggu akibat penyakit yang mereka idap. Dengan mengatasi gejala sesak napas akibat obstruksi saluran pernafasan, penderita asma dapat merasa lebih nyaman dan kualitas hidup mereka dapat ditingkatkan ${ }^{[6]}$.

Hingga kini, asma masih belum bisa disembuhkan atau dicegah secara efektiff[2]. Tanpa upaya pengelolaan penyakit asma yang efektif, sumber daya alam maupun sumber daya manusia akan tersia-siakan. Anggaran yang seharusnya dapat digunakan untuk pengembangan sektor vital lain, seperti pendidikan akan dialokasikan untuk mendukung sektor kesehatan. Seperti yang terjadi pada Maret 2020, Kementerian Pendidikan dan Kebudayaan memutuskan untuk mengalokasikan anggaran 405 Miliar Rupiah dari sektor pendidikan untuk penanganan dan pencegahan wabah COVID-19[7]. "Kita tidak bisa berbicara banyak tentang kemajuan pendidikan jika tingkat ekonominya rendah, atau tidak bertumbuh dengan baik..." ujar Mantan Wakil Presiden RI Jusuf Kalla dalam acara pemberian gelar Doktor Kehormatan beliau ${ }^{[8]}$. Dengan ini, jelas bahwa upaya mengatasi gejala asma, seperti menangani dan mencegah serangan asma yang tidak efektif akan merugikan negara.

Hingga saat ini, terdapat 2 jenis obat yang digunakan dalam penanganan asma, yaitu obat pelega dan obat pengontrol. Obat pelega adalah obat yang digunakan saat serangan asma. Obat pelega terdiri dari bronkodilator dan kortikosteroid sistemik. Bronkodilator yang dipakai adalah ipratropium bromida dan agonis $\beta 2$ kerja cepat. Sedangkan obat yang digunakan untuk pencegahan serangan asma adalah obat pengontrol yang harus diberikan terus menerus dalam jangka yang panjang. Obat pengontrol antara lain inhalasi kortikosteroid, antileukotrien, agonis $\beta 2$ kerja panjang dan teofilin lepas lambat ${ }^{[9]}$. Mengingat bahwa asma bukan merupakan penyakit baru, Indonesia 
telah lama menggunakan obat-obatan asma yang telah disampaikan. Namun, angka kematian akibat penyakit asma masih tinggi. Untuk dapat mencapai SDGs 2030, meningkatkan kualitas hidup pengidap asma, dan mendukung kemajuan Bangsa Indonesia, perlu adanya solusi baru untuk mengatasi gejala serangan asma. Oleh karena itu, penulis mengajukan penggunaan ekstrak daun Camellia sinensis sebagai bronkodilator alternatif dalam terapi asma.

\section{METODE}

Penulisan tinjauan pustaka ini dilakukan melalui analisis serta sintesis dari sumber ilmiah yang terpercaya dengan menggunakan beberapa kata kunci, antara lain yaitu asma, C. sinensis, dan kafein. Selanjutnya penulis memilah sumber ilmiah relevan yang berbentuk full-text. Penulis mendapatkan sumber referensi dari database seperti International Library of Medicine (Pubmed), dan Google Scholar. Terdapat sekitar 27 sumber ilmiah dianalisis dan ditinjau dalam artikel ini.

\section{PEMBAHASAN}

\subsection{Asma: Penyakit Respiratorik} Umum yang Dapat Berakibat Fatal

Menurut WHO, asma adalah kondisi paru-paru yang menyebabkan penderitanya kesulitan bernafas. Kondisi paru yang dimaksud adalah obstruksi dan penyempitan saluran pernapasan. Pada umumnya, asma banyak diderita oleh anak-anak meskipun asma juga dapat diderita oleh orang dewasa pada usia berapa pun. Saat ini, asma belum bisa disembuhkan. Obat-obatan yang ada hanya mampu mengatasi serangan asma yang dialami oleh penderitanya. Dengan manajemen gejala asma yang baik, penderita dapat meningkatkan kualitas hidupnya ${ }^{[10,11]}$.

$$
\text { Asma sebagai penyakit }
$$
multifaktorial dipicu oleh faktor genetik dan banyak faktor lingkungan. Dalam sebuah penelitian yang berjudul $A n$ Understanding of the Genetics Basis of Asthma oleh Bijanzadeh M, Mahesh PA, dan Ramachandra NB, dikatakan kemungkinan asma untuk diturunkan pada generasi berikutnya sebesar $79 \%$, sedangkan $21 \%$ sisanya ditentukan oleh faktor lingkungan. Angka heritabilitas asma yang tinggi memudahkan orang untuk menderita asma jika keluarganya memiliki riwayat menderita asma juga. Tidak hanya faktor genetik, tetapi faktor lingkungan seperti alergi, infeksi, polusi udara, rokok, dan obesitas juga memicu asma pada sesorang ${ }^{[12,13,14]}$.

Akibat penyempitan saluran pernapasan, penderita asma akan mengalami gejala batuk (terutama pada malam hari, saat berolahraga atau sedang tertawa), kesulitan bernafas, sesak dada, nafas pendek, dan wheezing (suara dengan frekuensi tinggi yang terdengar saat menghembuskan nafas) ${ }^{[13]}$. Penderita asma juga dapat mengalami serangan asma. Meski serangan asma dapat dicegah dan diatasi, serangan asma dapat berakibat fatal jika tidak ditangani dengan baik. Serangan asma yang dimaksud adalah kondisi saat penderita asma mengalami kesulitan bernapas yang berlebihan secara tiba-tiba. Durasi serangan asma sangat bervariasi dan bergantung pada penyebabnya dan berapa lama saluran pernapasan mengalami inflamasi ${ }^{[10,15]}$. Untuk mengatasi dan mencegah terjadinya serangan asma, obat pelega dan obat pengontrol harus diberikan ${ }^{[9]}$.

Obat pelega dapat membantu penderita saat mengalami serangan asma. Obat pelega terdiri dari bronkodilator dan kortikosteroid sistemik. Bronkodilator yang digunakan adalah ipratropium bromida dan agonis $\beta 2$ kerja cepat. Pemberian bronkodilator kepada penderita asma dilakukan dengan cara dihirup menggunakan nebuliser. Jika kondisi penderita dan situasi tidak memungkinkan, maka metered dose inhalers (MDI) atau inhalasi dosis terkurur (IDT) dengan alat bantu (spacer). Selain obat pelega, juga ada obat pengontrol yang berfungsi untuk mencegah terjadinya serangan asma. Obat ini digunakan dalam jangka panjang. Pada umumnya, obat pengontrol yang digunakan adalah inhalasi kortikosteroid, antileukotrien, agonis $\beta 2$ kerja panjang, dan teofilin lepas lambat ${ }^{[9]}$. 
Tabel 1. Jenis obat asma ${ }^{[9]}$

\begin{tabular}{|c|c|c|c|}
\hline Jenis obat & Golongan & Nama generik & Bentuk/kemasan obat \\
\hline \multirow[t]{5}{*}{$\begin{array}{l}\text { Pengontrol } \\
\text { (Antiinflamasi) }\end{array}$} & Steroid inhalasi & $\begin{array}{l}\text { Flutikason propionat } \\
\text { Budesonide }\end{array}$ & $\begin{array}{l}\text { IDT } \\
\text { IDT, turbuhaler }\end{array}$ \\
\hline & Antileukokotrin & Zafirlukast & Oral(tablet) \\
\hline & $\begin{array}{l}\text { Kortikosteroid } \\
\text { sistemik }\end{array}$ & $\begin{array}{l}\text { Metilprednisolon } \\
\text { Prednison }\end{array}$ & $\begin{array}{l}\text { Oral(injeksi) } \\
\text { Oral }\end{array}$ \\
\hline & $\begin{array}{l}\text { Agonis beta-2 } \\
\text { kerjalama }\end{array}$ & $\begin{array}{l}\text { Prokaterol } \\
\text { Formoterol } \\
\text { Salmeterol }\end{array}$ & $\begin{array}{l}\text { Oral } \\
\text { Turbuhaler } \\
\text { IDT }\end{array}$ \\
\hline & $\begin{array}{l}\text { kombinasi steroid dan } \\
\text { Agonis beta-2 } \\
\text { kerjalama }\end{array}$ & $\begin{array}{l}\text { Flutikason + Salmeterol } \\
\text { Budesonide + formoterol }\end{array}$ & $\begin{array}{l}\text { IDT } \\
\text { Turbuhaler }\end{array}$ \\
\hline \multirow[t]{6}{*}{$\begin{array}{l}\text { Pelega } \\
\text { (Bronkodilator) }\end{array}$} & $\begin{array}{l}\text { Agonis beta- } 2 \text { kerja } \\
\text { cepat }\end{array}$ & Salbutamol & $\begin{array}{l}\text { Oral, IDT, rotacap } \\
\text { solution }\end{array}$ \\
\hline & & Terbutalin & $\begin{array}{l}\text { Oral, IDT, turbuhaler, } \\
\text { solution, ampul (injeksi) }\end{array}$ \\
\hline & & Prokaterol & IDT \\
\hline & Antikolinergik & $\begin{array}{l}\text { Fenoterol } \\
\text { Ipratropium bromide }\end{array}$ & $\begin{array}{l}\text { IDT, solution } \\
\text { IDT, solution }\end{array}$ \\
\hline & Metilsantin & $\begin{array}{l}\text { Teofilin } \\
\text { Aminofilin } \\
\text { Teofilin lepas lambat }\end{array}$ & $\begin{array}{l}\text { Oral } \\
\text { Oral, injeksi } \\
\text { Oral }\end{array}$ \\
\hline & $\begin{array}{l}\text { Kortikosteroid } \\
\text { sistemik }\end{array}$ & $\begin{array}{l}\text { Metilprednisolon } \\
\text { Prednison }\end{array}$ & $\begin{array}{l}\text { Oral, inhaler } \\
\text { Oral }\end{array}$ \\
\hline
\end{tabular}

3.2 Camellia sinensis:

\section{Pengembangan Sumber Daya Alam dalam Penanganan Asma}

Camellia sinensis (C. sinensis)

adalah spesies tanaman dengan daun dan kuncup daun yang dapat digunakan untuk memproduksi minuman teh. $C$. sinensis berasal dari genus Camellia dan famili Theaceae. Meski hampir semua jenis teh berasal dari daun $C$. sinensis, pemrosesan yang berbeda menghasilkan teh dengan aroma dan tingkat oksidasi yang khas. C. sinensis adalah tanaman asli Asia Timur, Selatan dan Tengara. Namun, $C$. sinensis yang dibudidayakan di seluruh dunia baik bagian tropis maupun subtropis memudahkan masyarakat untuk memanfaatkan spesies tanaman ini ${ }^{[16]}$.

Sejak dulu, C. sinensis digunakan untuk pengobatan karena kaya akan komponen bioaktif ${ }^{[17]}$. C. sinensis mengandung lebih dari 4000 metabolit, dimana lebih dari satu per tiganya berasal dari kelompok polifenol[18]. Polifenol yang ditemukan dalam daun $C$. sinensis adalah flavonoids. Selain polifenol, terdapat zat asam amino, protein, senyawa organik yang mudah menguap (volatile), alkaloid (kafein, teobromin, dan teofilin), karbohidrat, dan klorofil ${ }^{[19]}$.

\subsection{Potensi Ekstrak Daun C. sinensis sebagai Upaya Preventif terhadap Serangan Asma}

Ekstrak C. sinensis yang dikenal sebagai teh memiliki konsentrasi konten yang sangat bervariasi, tergantung pada cara penumbuhan, pengelolaan, dan ekstraksi daun teh. Meski demikian, kafein adalah komponen utama dalam ekstrak daun $C$. sinensis. Horzic et al melakukan penelitian yang mengevaluasi konten kafein pada berbagai jenis teh. Hasil penelitiannya menunjukkan peningkatan konten kafein sebagai berikut: teh oolong $(156 \mathrm{mg} / \mathrm{l})<$ teh hitam $(184 \mathrm{mg} / \mathrm{l})<$ teh putih (198 $\mathrm{mg} / \mathrm{l})<$ teh hijau $(297 \mathrm{mg} / \mathrm{l})$. Namun, masih diperlukan penelitian lebih lagi tentang dosis ekstrak daun C.sinensis yang efektif untuk mencegah serangan asma $^{[20]}$.

Kafein adalah zat alkaloid dari golongan methylxantine yang ditemukan dalam biji, kacang, atau daun berbagai tanaman, termasuk Camellia sinensis ${ }^{[20]}$. Usai dikonsumsi, kafein akan diabsorpsi dan didistribusikan ke semua organ tubuh. Lalu, kafein akan mempengaruhi fisiologi tubuh. Kafein akan menginhibisi enzim fosfodiesterase sehingga cyclic adenosine monophosphate (cAMP) tidak dihidrolisis. CAMP berfungsi sebagai caraka kimia kedua (second messenger) yang meregulasi fungsi kontraksi dan relaksasi otot polos. Selain itu, methylxanthine juga bersifat antagonis terhadap reseptor adenosin yang memicu bronkokonstriksi. Maka methylxantine dapat digunakan sebagai bronkodilator dalam pengobatan asma $^{[22]}$. Dalam dosis kecil, kafein mampu meningkatkan fungsi paru-paru selama 4 jam setelah ingesti. Maka ekstrak daun C.sinensis memiliki potensi untuk digunakan dalam pencegahan serangan asma ${ }^{[22]}$.

\subsection{Keamanan Ekstrak Daun C. Sinensis bagi Tubuh}

Teh kini bukan hanya sekadar minuman, melainkan sudah menjadi bagian dari gaya hidup. Ekstrak daun $C$. sinensis aman untuk dikonsumsi semua orang tanpa batas umur. Namun, kafein dapat berdampak negatif pada tubuh jika jumlah asupan kafein melebihi batas normal yaitu $100 \mathrm{mg}$ per hari. Gejala yang dapat terjadi jika konsumsi kafein 
berlebihan adalah kegelisahan, insomnia, kadar gula darah tinggi, dan tekanan darah tinggi. Tidak hanya itu, konsumsi kafein berlebihan (>3 $\mathrm{mg} / \mathrm{kgBB}$ ) dengan obat-obatan lain dapat menyebabkan kematian. Jika konsumsi kafein masih dalam jumlah yang moderat (kurang dari $3 \mathrm{mg} / \mathrm{kgBB}$ ), kecil kemungkinannya dampak negatif tersebut terjadi $[23,24,25]$.

\subsection{Menunjang Pertumbuhan Negara yang Sedang Berkembang}

Produksi teh secara global telah meningkat secara signifikan, dari 3891,2 ton pada tahun 2006 menjadi 5063,9 ton pada tahun 2013. Pada tingkat nasional, terdapat kenaikan produksi teh di Indonesia dari 150,3 ton pada tahun 2006 menjadi 152,7 ton pada tahun $2013^{[26]}$. Peningkatan angka produksi ini membuat daun teh atau $C$. sinensis sangat mudah untuk ditemukan dan dimanfaatkan oleh semua masyarakat. Selain itu, teh yang digolongkan sebagai komoditas memiliki harga yang ekonomis sehingga masyarakat kelas menengah, bawah ataupun atas mampu membelinya. Indonesia sebagai negara berkembang memiliki kesempatan yang besar untuk memanfaatkan sumber daya alam yang terjangkau namun berkhasiat inil $^{[26]}$.

\section{KESIMPULAN}

Melihat fakta bahwa asma menjadi salah satu penyakit respiratorik utama di Indonesia dengan pervalensi yang terus meningkat, Indonesia memerlukan terapi dan pengobatan yang baru dan efektif untuk mengatasi dan mencegah gejala asma, khususnya serangan asma. Meskipun obat-obatan ini dapat mengatasi serangan asma pada penderita asma, angka kematian akibat asma yang masih tinggi menunjukkan obat-obat ini belum cukup efektif.

Kandungan kafein dalam daun Camellia sinensis dapat berfungsi sebagai bronkodilator sehingga penggunaan ekstrak daun $C$. sinensis dapat menjadi solusi yang tepat dalam upaya preventif terhadap serangan asma dan menurunkan angka mortalitas asma. Selain itu, ekstrak daun $C$. sinensis yang telah dikonsumsi masyarakat sejak dahulu membuktikan keamanan untuk konsumsi. Produksi teh di berbagai negara termasuk Indonesia membuat teh mudah untuk didapatkan dalam harga yang lebih ekonomis. Sehingga masyarakat dari kelas ekonomi menengah dan bawah pun mampu untuk menikmati manfaat ekstrak daun $C$. sinensis. Penggunaan ekstrak daun $C$. sinensis sebagai upaya preventif terhadap serangan asma masih perlu dikembangkan agar manfaat sumber daya alam tersebut dapat dimaksimalkan.

\section{DAFTAR PUSTAKA}

1. Dharmage SC, Perret JL, Custovic A. Epidemiology of asthma in children and adults. Front Pediatr [Internet]. 2019 Jun 18 [Cited 2021 Apr 20];7:246. Available from: https://www.ncbi.nlm.nih.gov/pm c/articles/PMC6591438/

2. Forum of International Respiratory Societies. The global impact of respiratory disease. 2nd ed. Sheffield: European Respiratory Society; 2017.

3. Strachan D, Limb E, Pearce N, Marks G, Morales E, PerezFernandez V. Asthma mortality [Internet]. The global asthma report 2018; [Cited 2021 Apr 20]. Available from: http://globalasthmareport.org/bu rden/mortality.php

4. Khairani. Penderita asma di indonesia. Jakarta: Infodantin Pusat Data dan Informasi Kementrian Kesehatan RI; 2019.

5. International NGO Forum on Indonesian Development. Tujuan $03 \quad$ [Internet]. International NGO Forum on Indonesian Development; [Cited 2021 Apr 20]. Available from: https://www.sdg2030indonesia.o rg/page/11-tujuan-tiga

6. Pujo MS, Kartini K. Peningkatan derajat obstruksi saluran nafas menurunkan kualitas hidup penderita asma. J Biomedika Kesehatan [Internet]. 30 Sep 
2019 [Cited 2021 Apr 20];2(3):99-03. Available from: https://jbiomedkes.org/index.php /jbk/article/view/86

7. Biro Kerja Sama dan Hubungan Masyarakat Kemendikbud. Kemendikbud realokasi anggarap rp405 miliar untuk penanganan covid-19 [Internet]. Jakarta: Kemendikbud; 2020 Maret 27 [Cited 2021 Apr 20]. Available from: https://www.kemdikbud.go.id/ma in/blog/2020/03/kemendikbudrealokasi-anggaran-rp405miliar-untuk-penanganancovid19

8. Mantan wapres jk sebut pendidikan kunci kemajuan bangsa [Internet]. Universitas Negeri Padang; 2019 Jun 12 [Cited 2021 Apr 20]. Available from:

http://www.unp.ac.id/id/kiprah/m antan-wapres-jk-sebut-

pendidikan-kunci-kemajuanbangsa

9. Menteri Kesehatan Republik Indonesia. Pedoman pengendalian penyakit asma. Jakarta: Menteri Kesehatan Republik Indonesia; 2008 Nov 3. 43 p. Report No.: 1023/MENKES/SK/XI/2008

10. World Health Organization. Asthma [Internet]. WHO; 2019 Nov 24 [Cited 2021 Apr 20]. Available from: https://www.who.int/news$\mathrm{room} / \mathrm{q}$-a-detail/asthma

11. Global Initiative for Asthma. Pocket guide for asthma management and prevention. 2020 Apr 3.

12. Holgate ST, Wenzel S, Postma DS, Weiss ST, Renz H, Sly PD. Asthma. Nat Rev Dis Primers [Internet]. 2016 Sep 10 [Cited 2021 Apr 20];1(1):15025. Available from: https://www.ncbi.nlm.nih.gov/pm c/articles/PMC7096989/
13. Asthma symptoms [Internet]. American College of Allergy, Asthma \& Immunology; [Updated 2018 Apr 17, Cited 2021 Apr 20]. Available from: https://acaai.org/asthma/asthma -symptoms

14. Bijanzadeh $M$, Mahesh $P A$, Ramachandra NB. An understanding of the genetic basis of asthma. Indian $\mathrm{J}$ Med Res [Internet]. 2011 Aug [Cited 2021 Apr 20];134(2):149-161. Available from: https://www.ncbi.nlm.nih.gov/pm c/articles/PMC3181014/

15. Asthma attack [Internet]. American College of Allergy, Asthma \& Immunology; [Cited 2021 Apr 21]. Available from: https://acaai.org/asthma/sympto ms/asthma-attack

16. Teapedia. Camella sinensis [Internet]. The Tea Encyclopedia; [Updated 2019 Des 31, Cited 2021 Apr 21]. Available from: http://teapedia.org/en/Camellia sinensis

17. Khan N, Mukhtar H. Tea and health: studies in humans. Curr Pharm Des [Internet]. 2013 [Cited 2021 Apr 21];19(34):61416147. Available from: https://www.ncbi.nlm.nih.gov/pm c/articles/PMC4055352/

18. Koch W, Zagórska J, Marzec Z, Kukula-Koch W. Applications of tea (camellia sinensis) and its active constituents in cosmetics. Molecules [Internet]. $2019 \mathrm{Nov}$ 24 [Cited 2021 Apr 21];24(23):4277. Available from: https://www.ncbi.nlm.nih.gov/pm c/articles/PMC6930595/

19. Goenka P, Sarawgi A, Karun V, Nigam AG, Dutta S, Marwah N. Camellia sinensis (tea): implications and role in preventing dental decay. Pharmacogn Rev [Internet]. 2013 [Cited 2021 Apr 21];7(14):152-156. Available 
from:

https://www.ncbi.nlm.nih.gov/pm c/articles/PMC3841993/

20. Gramza-Michalowska A. Caffeine in tea camellia sinensis - content, absorption, benefits and risks of consumption. J Nutr Health Aging. 2014; 18(2):143-9

21. Sanchez JM. Methylxanthine content in commonly consumed foods in spain and determination of its intake during consumption [Internet]. Foods. 2017 Dec 4 [Cited 2021 Apr 21]: 6(12); 109. Available from: https://www.ncbi.nlm.nih.gov/pm c/articles/PMC5742777/

22. Gottwalt B, Tadi P. Methylxanthines. In: StatPearls [Internet]. Treasure Island (FL): StatPearls Publishing; 2021 Jan [Updated 2021 Jan 31, Cited 2021 Apr 20]. Available from: https://www.ncbi.nlm.nih.gov/bo oks/NBK559165/

23. Harvard Medical School. What is it about coffee? [Internet]. Harvard Health Publishing; 2012 Jan [Cited 2021 Apr 21]. Available from: https://www.health.harvard.edu/ staying-healthy/what-is-it-aboutcoffee

24. Sagon C. Caffeine for your health - too good to be true? [Internet]. AARP; [Cited 2021 Apr 21]. Available from: https://www.aarp.org/health/heal thy-living/info-10-2013/coffeefor-health.html

25. Temple JL, Bernard C, Lipshultz SE, Czachor JD, Westphal JA, Mestre MA. The safety of ingested caffeine: a comprehensive review. Front Psychiatry [Internet]. 2017 May 26 [Cited 2021 Apr 20];8:80. Available from: https://www.ncbi.nlm.nih.gov/pm c/articles/PMC5445139/

26. Chang K. World tea production and trade current - current and future development. Food and
Agriculture Organization of the United Nations; 2015

27. Kolk HA. Tea as cultural commodity [Internet]. Common Reader; 2019 Aug 28 [Cited 2021 Apr 20]. Available from: https://commonreader.wustl.edu /c/tea-as-cultural-commodity/ 